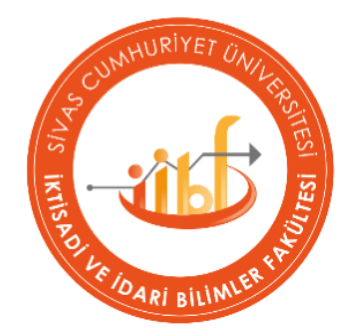

\title{
THE RELATIONSHIP BETWEEN DETERMINANTS OF SHOPPING SITES AND CUSTOMER TRUST, PURCHASE INTENTION, SATISFACTION, AND REPURCHASE
}

\author{
Serhat ATA ${ }^{1}$ \\ Abdulvahap BAYDAS ${ }^{2}$ \\ Mehmet Emin YAŞAR ${ }^{3}$
}

\section{Abstract}

In recent years, the Internet has caused radical changes in business and social life, one of which is online purchasing. The online purchasing status of consumers can be affected by many factors. One of these factors is website determinants. These determinants overwhelmingly shape consumers' behaviors and loyalty in the future. For consumers, online shopping involves more uncertainties than physical shopping. Especially in the current period, even daily basic needs are made with online shopping, which makes this situation even more difficult for both e-commerce businesses and customers. The aim of this study is to reveal the mediating role of customer e-trust in the relationship between determinants of shopping websites and online purchase intention, satisfaction, and repurchase intention of customers. In this research, based on the literature review, the questionnaire method was applied to 321 participants, only in Bingöl province of Turkey and via e-mail between September and December 2020. The convenience sampling method was used in the choice of the people participating in the study. The population of the research consists of consumers only preferring online shops. For testing the hypotheses, first-factor analysis was conducted, and to reveal mediation effect, multiple regression analysis was applied. In line with this, findings show that image, interface, security, and privacy subdimensions of web determinants positively affect meaningful purchase intention, customer satisfaction, and repurchase of customers. Besides, it was found that e-trust has a partial mediating role in this relationship. The most important limitation in the findings of this study is that the study only covers the consumers in a certain city. Website user intentions may vary in different cities, cultures, countries, regions, and from education levels. In future studies, in addition to these variables, hedonic purchasing, following fashion, planned purchasing behaviors, as well as brand perception, which are effective in customers' preference of online shopping sites, can be added to examine their effect on existing variables.

\section{Article History:}

Date submitted:

5 August 2021

Date accepted:

9 September 2021

Jel Codes:

M30, M31,M39

\section{Keywords:}

Website Determinants, Purchase Intention, Customer Satisfaction, Repurchase, E-Trust

Suggested Citation: Ata, S. \& Baydaş, A. \& Yaşar, M. E. (2021). The Relationship Between Determinants of Shopping Sites and Customer Trust, Purchase Intention, Satisfaction, and Repurchase. Cumhuriyet University Journal of Economics and Administrative Sciences, 22(2), 324-349.

1 Res. Asst., Duzce University, Faculty of Business, Department of International Trade and Finance, serhatata@duzce.edu.tr, ORCID ID: 0000-0002-5423-5118

2 Prof. Dr., Duzce University, Faculty of Business, Department of Business, abdulvahapbaydas@duzce.edu.tr, ORCID ID: 0000-0001- 2345-6789

${ }^{3}$ Lect., Bingol University, Solhan Vocational School of Health Services, Department of Medical Services and Techniques, meyasar@bingol.edu.tr, ORCID ID: 0000-0001-8137-2946. 


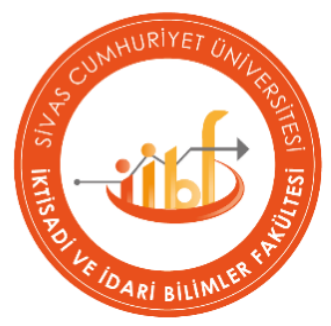

\section{ALISVERISS SITELERİ BELİRLEYİCILERIYLE TÜKETİCI GÜVENI, ÇEVRIMIÇI SATIN ALMA NIYYETİ, TATMIN VE YENIDEN SATIN ALMA İLișKisis}

\section{Serhat ATA ${ }^{1}$}

Abdulvahap BAYDAŞ ${ }^{2}$

Mehmet Emin YASAR ${ }^{3}$

\section{$\ddot{O ̈ z}$}

Son yıllarda internet, işletmelerde ve sosyal hayatta radikal değişikliklerin yaşanmasına neden olmuştur. Bunlardan bir tanesi de online satın almadır. Tüketicilerin online satın alma durumu birçok faktörden etkilenebilmektedir. Bu faktörlerden biri web sitesi belirleyicileridir. Bu belirleyiciler tüketicilerin gelecekteki davranışlarını ve sadakatlerini büyük ölçüde şekillendirmektedir. Tüketiciler için online alışveriş, fiziksel alışverişten daha fazla belirsizlikler içermektedir. Özellikle içinde bulunulan dönemde günlük temel ihtiyaçların dahi online alışveriş ile yapılması bu durumu hem tüketiciler için hem de e-ticaret işletmeleri için daha da zorlaştırmaktadır. Bu çalışmanın amacı web sitesi belirleyicilerinin online satın alma niyeti, tüketici tatmini ve yeniden satın alma niyeti üzerindeki etkisini belirlemek ve bu etkide tüketici e-güveninin düzenleyici rolünü ortaya çıkarmaktır Araştırmanın evrenini sadece online alışveriş yapan tüketiciler oluşturmaktadır. Bu araştırmada, literatür taramasına dayalı olarak, Eylül-Aralık 2020 tarihleri arasında Türkiye'nin sadece Bingöl ilinde ve e-posta yoluyla 321 katılımcıya anket yöntemi uygulanmıştır. Araştırmaya katkı sağlayacak kişilerin seçiminde ise kolayda örnekleme yöntemi kullanılmıştır. Hipotezleri test etmek için ilk olarak faktör analizi yapılmış ve aracılık etkisini ortaya çıkarmak için çoklu regresyon analizi uygulanmıştır. Bulgular web sitesi görüntüsünün, ara yüzünün, güvenliğinin ve gizliliğinin satın alma niyeti, tüketici tatmini ve yeniden satın alma niyeti üzerinde pozitif ve anlaml etkiye sahip olduğunu göstermektedir. Bununla birlikte bu ilişkide tüketici e-güveninin kısmi düzenleyici role sahip olduğu bulgusuna ulaşılmıştır. Bu çalışmadaki en önemli sınırlılık, çalışmanın sadece belirli bir ildeki tüketicileri kapsamasıdır. Web sitesi kullanıcı niyetleri farklı şehir, kültür, ülke, bölge ve ĕgitim seviyelerine göre değişebilir. Illeride yapılacak çalışmalarda bu değişkenlere ek olarak müşterilerin online alışveriş sitelerini tercih etmelerinde etkili olan hedonik satın alma, moday takip etme, planlı satın alma davranışları ve marka algısı eklenerek mevcut değişkenler üzerindeki etkileri incelenebilir.

\author{
Makale Geçmişi: \\ Iletilen Tarih: \\ 5 Ağustos 2021 \\ Kabul Tarihi: \\ 9 Eylül 2021
}

Jel Kodlar:
M30, M31,M39

Anahtar Kelimeler:

Web Sitesi

Belirleyicileri, Satın

Alma Niyeti, Müşteri

Tatmini, Yeniden Satın

Alma, E-Güven

Önerilen Alıntı: Ata, S. \& Baydaş, A. \& Yaşar, M. E. Alışveriş Siteleri Belirleyicileriyle Tüketici Güveni, Çevrimiçi Satın Alma Niyeti, Tatmin ve Yeniden Satın Alma İIlişkisi. Cumhuriyet Üniversitesi Íktisadi ve İdari Bilimler Dergisi, 22(2), 324-349.

${ }^{1}$ Arş. Gör., Düzce Üniversitesi, İşletme Fakültesi, serhatata@ duzce.edu.tr, ORCID ID: 0000-0002- 5423-5118

2 Prof. Dr., Düzce Üniversitesi, İşletme Fakültesi, abdulvahapbaydas@duzce.edu.tr, ORCID ID: 0000-00012345-6789

${ }^{3}$ Öğr. Gör., Bingöl Üniversitesi, Solhan Sağlık Hizmetleri Meslek Yüksekokulu, Tıbbi Hizmetler ve Teknikler Bölümü meyasar@bingol.edu.tr, ORCID ID: 0000-0001-8137-2946. 


\section{THE RELATIONSHIP BETWEEN DETERMINANTS OF SHOPPING SITES AND CUSTOMER TRUST, PURCHASE INTENTION, SATISFACTION, AND REPURCHASE}

\section{INTRODUCTION}

E-commerce is a substantial technology that runs a variety of services and the facility to look through a wide range of products and services to select from, it provides much information concerning certain products and services and it comforts customers to get more information in less time and make better decisions and acquire the best deals (Salehi et al.,2021). The explosive spreading out of electronic commerce (e-commerce) during the last few decades has had a considerable impact on the global shopping landscape. In a globally changing era, online websites with rapidly increasing numbers add a different dimension to the shopping habits of customers (Islam et al, 2021). In traditional shopping that is ongoing for years, people would go to a store to meet their needs, hang around for hours to find out the best selection, convey the product bought oneself. It meant that customers were obliged too much to endeavor and expend time to acquire the product wanted. While it has been more than a decade since E-commerce first advanced into business-to-customer (Shergill \& Chen, 2005), online shopping by dispelling the necessity for people to go to the store, and with just one click, millions of products with affordable prices can be accessed without exerting time and effort.

Even though online shopping has turn into an emergent new trend and an important purchasing channel, customers are still not very satisfied with the current case of the shopping style. As online shopping has become a dominant alternative to traditional shopping, website features, characteristics of products have a critical impact on customer e-trust and experience (Kuo \& Chen, 2011; Mallapragada et al., 2016). The most significant point triggering customers towards dissatisfaction is natural inadequacy for providing physical product experiences such as touching that is a sensory stimulus. No-touch conwtitutes a considerable obscurity related to the products and triggers dissatisfaction (Lee et al., 2017). To illustrate, Patel et al. (2020) associate the customer intention with the interface of mobile apps, and it is in the findings of the study that interface positively affects peoples' enjoyment that influences peoples' e-trust in mobile apps. To increase the e-trust of a website on customers, it is necessary to increase privacy, avoid hard-to-believe words, and focus on improving graphic and structure design as well as content design. On the other hand, the website should provide ease of use to its customers and contain security signs that will create e-trust in customers. Social and personal signs used in website design also increase the etrust in the website (Seckler, 2015).

Although there are many studies on e-commerce and shopping site in the world, there are not many studies conducted in Turkey about the relationship between website determinants and online customer e-trust (Qualati et al.,2021; Hague \& Mazumder, 2020) and satisfaction (Rita et al.,2019), repurchase intention (Suhaily \& Soelasih, 2017). Nowadays, as the rate of online shopping increases every year both in the world and in Turkey, it is important for businesses to determine which criteria will provide a competitive advantage. From this point of view, it is seen that the element of e-trust is one of the most important criteria when shopping online. When most factors are categorized as the determinants of websites in this study, image, interface, security, and privacy of websites for shopping are reviewed and conducted in the analysis.

\section{LITERATURE REVIEW}

\subsection{Determinants of website and customer e-trust}

Attractive visual images and the design of e-commerce websites boost website aesthetics and emotional appeal for the user (Cyr et al., 2009). When compared to traditional stores, creating 
Serhat ATA, Abdulvahap BAYDAŞ \& Mehmet Emin YAŞAR, 2021 Cilt: 22, Sayl: 2, ss.324-349.

a positive website image is an important issue in e-commerce because of the lack of concrete elements such as personnel interaction, products, and showcases in online shopping (Akroush and Al-Debei, 2015: 1358). Considering website determinants, it is inevitable for e-commerce businesses to reach product information, compare prices between offered product alternatives, and develop strategies against difficulties in paying prices (Çelik \& Dülek, 2020). A good website image may cause an e-commerce business to be perceived as delivering high quality, innovative offers, and excellent operational transactions. In e-commerce, e-trust has been shown to have an important positive influence on the intention to buy a product. Seckler et al. (2015) discussed how different website characteristics such as graphic design, content design, and structure design provide benefit to heighten e-trust or avert distrust. These characteristics provide awareness for customers regarding website image. Many researchers in the field of marketing acknowledge that corporate image and corporate reputation play critical roles in the purchasing behavior of customers. These two structures are important in developing and maintaining the loyalty of customers (Nguyen and Leblanc, 2001: 227). Having a weak ethical image of businesses reduces customer e-trust by negatively affecting the performance of businesses (Leonidou et al., 2013). Etrust and perceived risk in an online business have a significant impact on the quality of the website for customers in terms of purchase intention. In other words, it can be stated that the website brand is a critical factor affecting customer e-trust. Based on these findings, the following hypothesis is proposed:

\section{$H_{1}$ : Image of websites has a positive and significant effect on customer e-trust.}

Website visitors rely their perception of the site on the looks regarding interface such as ease of understanding (content), ease of navigation, and the quickness with which the pages open (Lal \& Katole, 2021). The online store atmosphere should contain all the elements used to design the website and layout, including examples such as background color and pattern, links, icons, general color scheme, font, and web borders (Chang \& Chen, 2008). A positive website image can increase security, e-trust, and purchase intent, as the usability reflects the structure of a system, the simplicity of using the website, the speed of locating an item, ease of perception on the website, consistent design patterns, and the ability to control users' movements within the system (Chen \& Teng, 2013). Chang and Chen (2008) in their research found that the quality of customer interface increases perceived security, e-trust, and e-commerce customer satisfaction. Therefore, the following hypothesis can also be proposed:

\section{$\mathrm{H}_{2:}$ Interface of websites has a positive and significant effect on customer e-trust.}

The security of websites refers to fraud and cheating attempts by hackers and the potential risk to lose security. Websites should communicate with their customers online, considering honesty and reliability issues to be able to persuade them to do online research. Although many online shopping sites have been secured with coding systems, people remain insecure. This anxiety is more psychological, but it is the most important obstacle to the adoption of online shopping (Hsiao, 2008). Offering the security guarantee by websites has a positive stimulus on consumer satisfaction (e-satisfaction). Moreover, security is also the most important factor in building e-trust (Ratnasari et al., 2021). Shodiq et al. (2018) put emphasis in their research that customers should be convinced by guaranteeing their security and ensuring a process of payment transactions immediately. In line with findings, the hypothesis is as follows: 


\section{THE RELATIONSHIP BETWEEN DETERMINANTS OF SHOPPING SITES AND CUSTOMER TRUST, PURCHASE INTENTION, SATISFACTION, AND REPURCHASE}

$H_{3}$ : Security of websites has a positive and significant effect on customer e-trust.

Websites around the world have put forward their own privacy policies or notices to address their customers' privacy concerns. These are descriptions of sites' practices for online collection, use and dissemination of personal information. Liu et al. (2004) found that a successful relationship between buyer and seller in the website is subjected to the level of the buyer's e-trust which is shown in their Privacy-E-trust-Behavioral Intention model. The model enlightens how privacy impacts e-trust and then, e-trust influences customer behavioral intention for online transactions. In addition to all these, consumers have anxiety related to websites asking for personal information in detail, and this can be considered as a factor affecting the sense of etrust. According to the research by Ginosar and Ariel (2017), customers consider that there should be various restrictions on websites requesting personal information. In consideration of these reviews, the hypothesis conducted is as follows:

\section{$H_{4}$ : Privacy policy of websites has a positive and significant effect on customer e-trust.}

Websites around the world have put forward their own privacy policies or notices to address their customers' privacy concerns. These are descriptions of sites' practices for online collection, use and dissemination of personal information. Liu et al. (2004) found that a successful relationship between buyer and seller in the website is subjected to the level of the buyer's e-trust which is shown in their Privacy-E-trust-Behavioral Intention model. The model enlightens how privacy impacts e-trust and then, e-trust influences customer behavioral intention for online transactions. In addition to all these, consumers have anxiety-related to asking websites for personal information in detail and this can be considered as a factor affecting the sense of e-trust. According to the research of Ginosar and Ariel (2017), customers consider that there should be various restrictions on websites requesting personal information. In consideration of these reviews, the hypothesis conducted is as follows:

$H_{4}$ : Privacy policy of websites has a positive and significant effect on customer e-trust.

\subsection{E-trust, purchase intention, satisfaction, and repurchase}

The lack of e-trust, which is one of the basic requirements when establishing online shopping relationships, can play an important deterrent role in online shopping. Satisfaction is thoroughly associated with customer attitudes and intentions, which are part of customer behavior and directly impact customers' positive behavioral intentions (Rita et al., 2019). Satisfaction in online shopping indicates the user's response to the output of an information system which can be measured by the dimensions of repeat purchases and repeat visits (Husain, 2019). Rust and Zahorik (1993) stated that greater customer satisfaction brings about greater intent to repurchase. Customer e-trust affects the willingness to buy by shaping the risk and benefit perceptions of the consumers. E-trust shows a significant role in deciding the online purchasing behavior of consumers, and low e-trust significantly reduces online shopping behavior such as intention, satisfaction, and repurchases (Rehman et al. 2019). Hypotheses are formed as follows:

$H_{5}$ : Customer e-trust has a positive and significant effect on purchase intention.

$H_{6:}$ Customer e-trust has a positive and significant effect on customer satisfaction.

$H_{7}$ : Customer e-trust has a positive and significant effect on repurchase.

\subsection{Determinants of Website and Intention, Satisfaction, Repurchase, and e-trust}


Serhat ATA, Abdulvahap BAYDAŞ \& Mehmet Emin YAŞAR, 2021 Cilt: 22, Sayl: 2, ss.324-349.

Electronic commerce systems include the properties of a machine and human elements. Effective website design requires both the provision of user factors and the study of these factors to provide the necessary elements on the websites. These factors are (1) to make users feel comfortable, (2) to increase satisfaction by creating enjoyable sites, (3) to make them fun for gamification, (4) to enable consumers to spend more time on the site and to revisit it, and (5) to increase the likelihood of purchasing (Hausman and Siekpe, 2009). It is considered within the context of literature that familiarity of a website by its determinants directly influences purchase intention, satisfaction, and repurchase. In line with these implications, Chang and Chen (2008) in their study found out that website quality affects perceived risk and purchase intention. Also, a brand of a website is a more critical indicator for customers than website quality and this refers to the awareness of a website. Furthermore, the study reveals that e-trust functions as a mediator in this relationship. Because website quality effects the e-trust, so, the e-trust based on this relation affects satisfaction and repurchase intention. Octavia and Tamerlane (2017) similarly found the existence of a substantial influence on the website's quality towards e-trust, and e-trust on the online purchase intentions. Since the central feature of the relationship between buyer and seller in e-commerce is e-trust (Lien et al., 2015) hypotheses are proposed as follows:

$H_{8}$ : Determinants of Website has a positive and significant effect on purchase intention.

$H_{8 a}$ : Image of websites has a positive and significant effect on purchase intention.

$H_{8 b}$ : Interface of websites has a positive and significant effect on purchase intention.

$H_{8 c}$ : Security of websites has a positive and significant effect on purchase intention.

$H_{8 d}$ : Privacy policy of websites has a positive and significant effect on purchase intention.

$H_{9}$ : Determinants of Website has a positive and significant effect on customer satisfaction.

$H_{9 a}$ : Image of websites has a positive and significant effect on customer satisfaction.

$H_{9 b}$ : Interface of websites has a positive and significant effect on customer satisfaction.

$H_{9 c}$ : Security of websites has a positive and significant effect on customer satisfaction.

$H_{9 d}$ : Privacy policy of websites has a positive and significant effect on customer satisfaction.

$H_{10}$ : Determinants of Website has a positive and significant effect on repurchase

$H_{10 a}$ : Image of website has a positive and significant effect on repurchase.

$H_{10 b:}$ Interface of websites has a positive and significant effect on repurchase.

$H_{10 c}$ : Security of websites has a positive and significant effect on repurchase.

$H_{10 d}$ : Privacy policies of websites have a positive and significant effect on repurchase.

When e-trust is discussed theoretically, trust can be defined as 'a state in which both parties are willing to transact with each other as long as each behaves appropriately. Reciprocal relations in the definition refer to a human dimension (e.g. emotions, attitudes, and moods) although ecommerce principally associated with B2C relation. Jones and George (1998) state 'moods and emotions interrelate with values and attitudes to adjust the experience of trust' meaning that evaluating the trustworthiness is dependent on the human condition which is contingent upon to change and progressive boundaries. This strengthens the importance of assessing and re-evaluating trustworthiness in continuing affairs (e.g. repurchase situations) in either an explicit or implicit 


\section{THE RELATIONSHIP BETWEEN DETERMINANTS OF SHOPPING SITES AND CUSTOMER TRUST, PURCHASE INTENTION, SATISFACTION, AND REPURCHASE}

way. So, the development of e-trust is more challenging in the e-commerce owing to both human dimensions and atmosphere of the channels. In addition to the consumer's perception of the ecommerce vendor's ability to meet privacy expectations, the development of trust has also been associated to numerous e-commerce vendor attributes, comprising website quality (Tirtayani and Sukaatmadja, 2018). This is because web site determinants can be impressive on customers' perceived risk, and it's significant in constructing e-trust concerning the company. Customers may experience cognitive dissonance about their decisions and e-trust may reduce likely cognitive dissonance before the purchase. Because, e-trust encourages the first purchase experience, guides the evaluation of the experience and by doing so, provides a basis for future repurchases (Kim et al., 2008). So, e-trust can be a mediating role in the relationship between website determinants and purchase intention, customer satisfaction, and repurchase.

$H_{11}$ : E-trust has a mediating role in the relationship between websites' determinants and purchase intention, customer satisfaction, and repurchase.

$H_{11 a}$ : E-trust has a mediating role on the relationship between security of websites and purchase intention.

$H_{11 b:}$ E-trust has a mediating role on the relationship between security of websites and customer satisfaction.

$H_{11 c}$ : E-trust has a mediating on the relationship between security of websites and repurchase.

$H_{11 d}$ : E-trust has a mediating role on the relationship between privacy of websites and purchase intention.

$H_{11 e}$ : E-trust has a mediating role on the relationship between privacy of websites and customer satisfaction.

$H_{11 f:}$ E-trust has a mediating role on the relationship between privacy of websites and repurchase.

$H_{11 g}$ : E-trust has a mediating role on the relationship between interface of websites and purchase intention.

$H_{11 h}$ : E-trust has a mediating role on the relationship between interface of websites and customer satisfaction.

$H_{11 i}$ : E-trust has a mediating role on the relationship between interface of websites and repurchase.

$H_{11 j:}:$ E-trust has a mediating role on the relationship between image of websites and purchase intention.

$H_{11 k}$ : E-trust has a mediating role on the relationship between image of websites and customer satisfaction.

$H_{11 l}$ : E-trust has a mediating role on the relationship between image of websites and repurchase. 
Serhat ATA, Abdulvahap BAYDAŞ \& Mehmet Emin YAŞAR, 2021 Cilt: 22, Sayl: 2, ss.324-349.

\section{METHODOLOGY AND RESEARCH MODEL}

The aim of this study is to disclose the mediating role of customer e-trust in the relationship between determinants of shopping websites and online purchase intention, satisfaction, and repurchase intention of customers.

The Process macro created by Hayes (2013) was loaded into the SPSS program (www.processmacro.org) to test the hypothesis suggesting that e-trust and its types have a mediation role. Hayes has developed macro (template models) software for 92 different models that help calculate moderation and mediation effects (Hayes, 2018). When the mediator variable and independent variable are evaluated together in the regression analysis, it should be observed that the effect of the independent variable on the dependent variable decreases or becomes zero. As seen in Figure 1, the symbolic models of the research were drawn.

In the creation of the model, the path from the independent variable to the dependent variable, "c path"; the way the independent variable goes to the dependent variable via the mediator, " $c{ }^{1}$ way"; the path from the independent variable to the mediator variable is called the "path a" and finally the path from the mediator variable to the dependent variable is called the "path b" (Hayes, 2018).

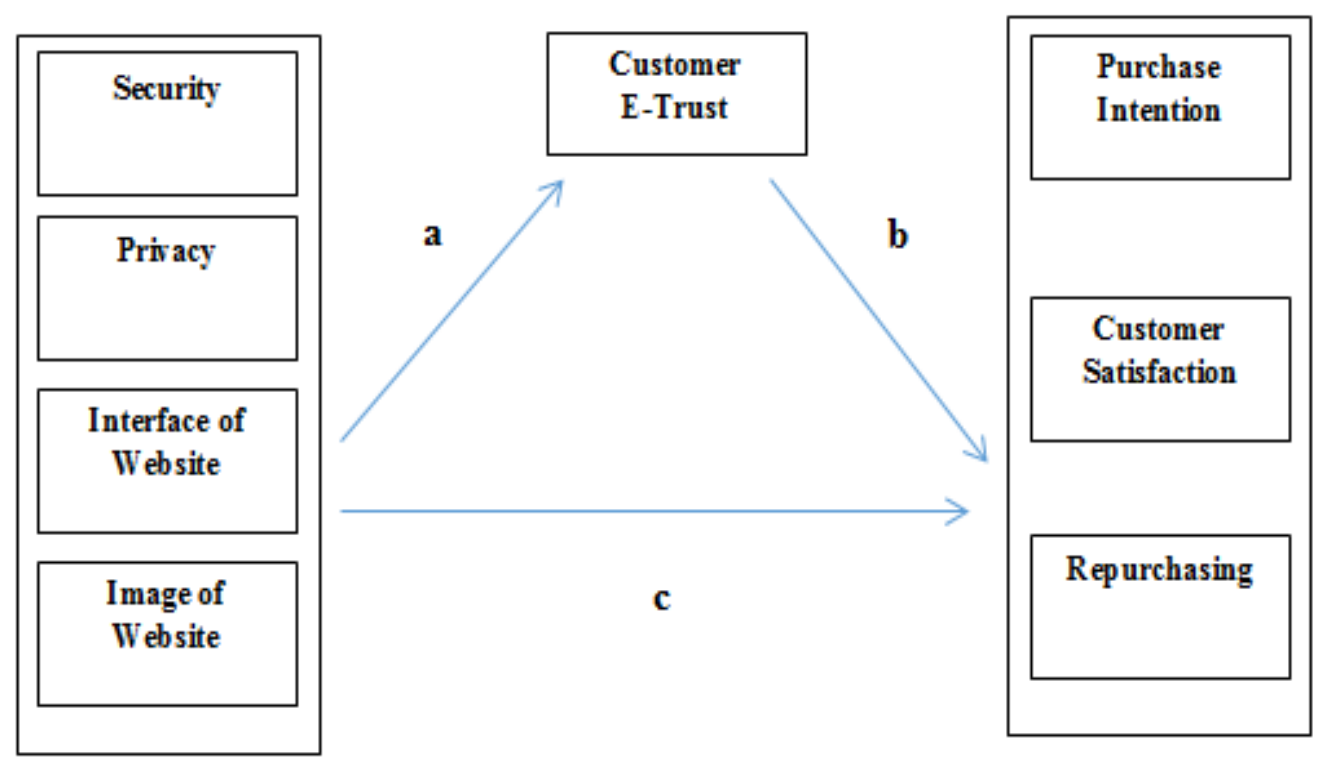

Figure 1: A model regarding a mediating role of e-trust in the relationship between websites' determinants and purchase intention, customer satisfaction, and repurchase

The model of the research is presented in Figure 1. According to this method, first, the effect of the independent variable, security, privacy, interface of website and image of website, on the customer e-trust that is mediator variable should be evaluated. Then, the effect of e-trust on purchase intention, customer satisfaction and repurchasing and then the effect of website determinants on purchase intention, customer satisfaction and repurchasing should be examined. 


\section{THE RELATIONSHIP BETWEEN DETERMINANTS OF SHOPPING SITES AND CUSTOMER TRUST, PURCHASE INTENTION, SATISFACTION, AND REPURCHASE}

\subsection{Research Methods}

The population of the research consists of consumers preferring online shops. The study sample consists of 321 consumers who reside in Bingöl, Turkey. According to e-commerce report of Ideasoft (2020) in 2021 only \%4.37 of population in East Anatolia region uses online shopping. When considering TUIK report (2021) regarding population rate, this region has approximately 6 million people. In line with this, Bingöl's population is only about 281.000 people (TUIK, 2020) and so, population of the research is considered about 7.000 people. Since no prior information is available, the minimum sample size to represent the population with a 5\% margin of error at the $5 \%$ significance level was obtained as 321 for this study. Participants were selected by a random method and out of online shopping, criterion were not included in the survey. In the research, the survey technique, one of the quantitative research methods, was chosen as the data collection method. The questionnaire form was applied in Bingöl province of Turkey and via e-mail between September and December 2020. The reason why Bingöl province is selected that in recent years it has high population growth rate (TUIK, 2020) and in line with this rate, according to statistics of 2020, it has some potential in the region for online shopping (Wordef.net). The convenience sampling method was used in the choice of the people to contribute to the study. It should be mentioned that the study is limited by doing research only in Bingöl province. The analysis only represents the sample. Accordingly, the obtained results couldn't be generalized.

Table 1: Distribution Regarding the Demographic Characteristics of the Participants

\begin{tabular}{|c|c|c|c|c|c|}
\hline Gender & $\mathbf{F}$ & $\%$ & Marital Status & $\mathbf{F}$ & $\%$ \\
\hline Male & 200 & 62,3 & Married & 180 & 56,1 \\
\hline Female & 121 & 37,7 & Single & 141 & 43,9 \\
\hline Total & 321 & 100 & Total & 321 & 100 \\
\hline Age & $\mathbf{F}$ & $\%$ & Occupation & $\mathbf{F}$ & $\%$ \\
\hline $15-24$ & 95 & 29,6 & Student & 102 & 31,8 \\
\hline $25-34$ & 115 & 35,8 & Public Employee & 27 & 8,4 \\
\hline $35-44$ & 15 & 4,7 & Private Sector Employee & 74 & 23,1 \\
\hline $45-54$ & 35 & 10,9 & Employer & 25 & 7,8 \\
\hline 55 and above & 61 & 19,0 & Retired Employee & 32 & 10,0 \\
\hline Total & 321 & 100 & Other & 61 & 19,0 \\
\hline Education & $\mathbf{F}$ & $\%$ & Total & 321 & 100 \\
\hline Primary Education & 39 & 12,1 & Income (Turkish Liras) & $\mathbf{F}$ & $\%$ \\
\hline High School & 64 & 19,9 & Under 1000 & 84 & 26,2 \\
\hline Associate Degree & 14 & 4,4 & $1001-3000$ & 37 & 11,5 \\
\hline Bachelor's Degree & 130 & 40,5 & $3001-5000$ & 129 & 40,2 \\
\hline Master/ Doctorate & 74 & 23,1 & $5001-7000$ & 31 & 9,7 \\
\hline \multirow[t]{2}{*}{ Total } & 321 & 100 & 7000 and above & 40 & 12,5 \\
\hline & & & Total & 321 & 100 \\
\hline
\end{tabular}


Serhat ATA, Abdulvahap BAYDAŞ \& Mehmet Emin YAŞAR, 2021 Cilt: 22, Sayl: 2, ss.324-349.

As seen in Table 1, approximately $62 \%$ of the participants were male, and $38 \%$ were female. When remarkable ranges regarding characteristics of participants were evaluated, about $65 \%$ of the participants were between 15-34 ages. Approximately $40 \%$ of participants had bachelor's degree and $56 \%$ were married. As occupation rates are viewed, $32 \%$ and $23 \%$ of the participants consisted of students and private-sector employees, respectively. When income statements were clarified, participants having income under 1000 Turkish liras comprised $26 \%$ and between 30015000 Turkish liras were viewed as $40 \%$.

Table 2: Online Shopping Experience and Frequency

\begin{tabular}{l|c|c}
\hline \multicolumn{1}{c|}{ Experience } & F & \% \\
\hline Under 1 year & 104 & 32 \\
1-3 years & 91 & 29 \\
4-6 years & 85 & 27 \\
7 years and above & 41 & 12 \\
Total & 321 & 100,0 \\
\hline
\end{tabular}

Table 2 shows the frequency of customers experiencing online shopping. Customers experiencing online shopping for less than 1 year account for $32 \%$. The ones between 1 and 3 years constituted $29 \%$ and $27 \%$ of the participants have experienced online shopping for 4-6 years.

Due to the nature of the research and time constraints, a questionnaire was used as a data collection tool. The questionnaire form was composed of two parts as "Likert scale questions" and "categorical questions". In the first part of the questionnaire form, the "security", "privacy", "interface", "image" dimensions of the websites were discussed. There were questions that measure the situation of these dimensions affecting the "e-trust" of consumers and the "satisfaction", "intentions" of online shoppers and, accordingly, their "loyalty" to repurchase from the same website. Scale questions were evaluated using a 5-point Likert scale $(1=$ Strongly Disagree, $2=$ Disagree, 3 = Undecided, $4=$ Agree, $5=$ Strongly Agree). The scale was comprised in line with Sönmezay (2019)'s master thesis associated with customer e-trust and online purchase intention. In this scale referenced, which was created using the literature, there were a total of 33 statements. In the second part of the questionnaire form, there were "categorical" questions regarding the characteristics of the respondents related to gender, marital status, age, education level, monthly income, and profession. In addition, the respondents were asked about how many years they had been shopping online. The data obtained were analyzed by using IBM SPSS 23 package program.

Exploratory factor analysis was performed to reveal the items and dimensions. KaiserMeyer-Olkin (KMO) sampling adequacy coefficient was found to be 0.905 , and Bartlett's test of sphericity was significant at the 0.00 level. Table 3 demonstrates the exploratory factor analysis and reliability analysis results. 
THE RELATIONSHIP BETWEEN DETERMINANTS OF SHOPPING SITES AND CUSTOMER TRUST, PURCHASE INTENTION, SATISFACTION, AND REPURCHASE

Table 3: Exploratory Factor Analysis and Reliability Scores

\begin{tabular}{|c|c|c|c|c|c|c|c|}
\hline $\begin{array}{c}\text { Factor 1: } \\
\text { Security }\end{array}$ & $\begin{array}{l}\text { Factor } \\
\text { Loads }\end{array}$ & $\begin{array}{c}\text { Variance } \\
\text { Explained }\end{array}$ & $\begin{array}{c}\text { Cronbach's } \\
\text { Alpha }\end{array}$ & $\begin{array}{c}\text { Factor 5: } \\
\text { E-trust }\end{array}$ & $\begin{array}{l}\text { Factor } \\
\text { Loads }\end{array}$ & $\begin{array}{c}\text { Variance } \\
\text { Explained }\end{array}$ & $\begin{array}{c}\text { Cronbach's } \\
\text { Alpha }\end{array}$ \\
\hline SEC1 & .882 & \multirow{4}{*}{11.41} & \multirow{4}{*}{.844} & TR1 & .692 & \multirow{4}{*}{8,12} & \multirow{4}{*}{.752} \\
\hline SEC2 & .854 & & & TR2 & .773 & & \\
\hline SEC3 & .871 & & & TR3 & .832 & & \\
\hline SEC4 & .765 & & & TR4 & .811 & & \\
\hline $\begin{array}{c}\text { Factor 2: } \\
\text { Privacy }\end{array}$ & & \multirow{6}{*}{8.65} & \multirow{6}{*}{.738} & $\begin{array}{l}\text { Factor 6: } \\
\text { Intention }\end{array}$ & & \multirow{6}{*}{8,73} & \multirow{6}{*}{.794} \\
\hline PR1 & .792 & & & INT1 & .861 & & \\
\hline PR2 & .673 & & & INT2 & .793 & & \\
\hline PR3 & .849 & & & INT3 & .873 & & \\
\hline PR4 & .855 & & & & & & \\
\hline PR5 & .737 & & & & & & \\
\hline $\begin{array}{l}\text { Factor 3: } \\
\text { Interface }\end{array}$ & & \multirow{6}{*}{8.56} & \multirow{6}{*}{.783} & $\begin{array}{c}\text { Factor 7: } \\
\text { Repurchase }\end{array}$ & & \multirow{6}{*}{10.02} & \multirow{6}{*}{.813} \\
\hline IF1 & .691 & & & RP1 & .742 & & \\
\hline IF2 & .871 & & & RP2 & .884 & & \\
\hline IF3 & .887 & & & RP3 & .812 & & \\
\hline IF4 & .755 & & & RP4 & .705 & & \\
\hline IF5 & .773 & & & RP5 & .822 & & \\
\hline $\begin{array}{c}\text { Factor 4: } \\
\text { Image }\end{array}$ & & \multirow{4}{*}{8,44} & \multirow{4}{*}{.771} & $\begin{array}{c}\text { Factor 8: } \\
\text { Satisfaction }\end{array}$ & & \multirow{4}{*}{7,30} & \multirow{4}{*}{.717} \\
\hline IM1 & .751 & & & ST1 & .657 & & \\
\hline IM2 & .814 & & & ST2 & .702 & & \\
\hline IM3 & .865 & & & ST3 & .721 & & \\
\hline
\end{tabular}

Total Variance Explained: 71, $23 \%$

Within the scope of the factor analysis, all items were accounted for 8 factors within the score of loads and only one item (from repurchase) from the model was removed due to the crossfactor loadings. Additionally, when variances cumulatively calculate, 8 factors explained 71, $23 \%$ of the model. To get reliability scores of all factors Cronbach's Alfa values were calculated and considering the given value ranges (Wainer and Tissen, 1996), it is seen that the reliability analysis results for all dimensions are highly reliable. 
Serhat ATA, Abdulvahap BAYDAŞ \& Mehmet Emin YAŞAR, 2021 Cilt: 22, Sayl: 2, ss.324-349.

\section{RESULTS}

In this section, for the purpose of revealing the relationship between determinants of website (independent variables) and purchase intention, customer satisfaction, and repurchase (dependent variables) and to test mediating role of e-trust on this relationship regression analysis and process methods were performed. Figure 2 shows an alternative model 1 for mediation role

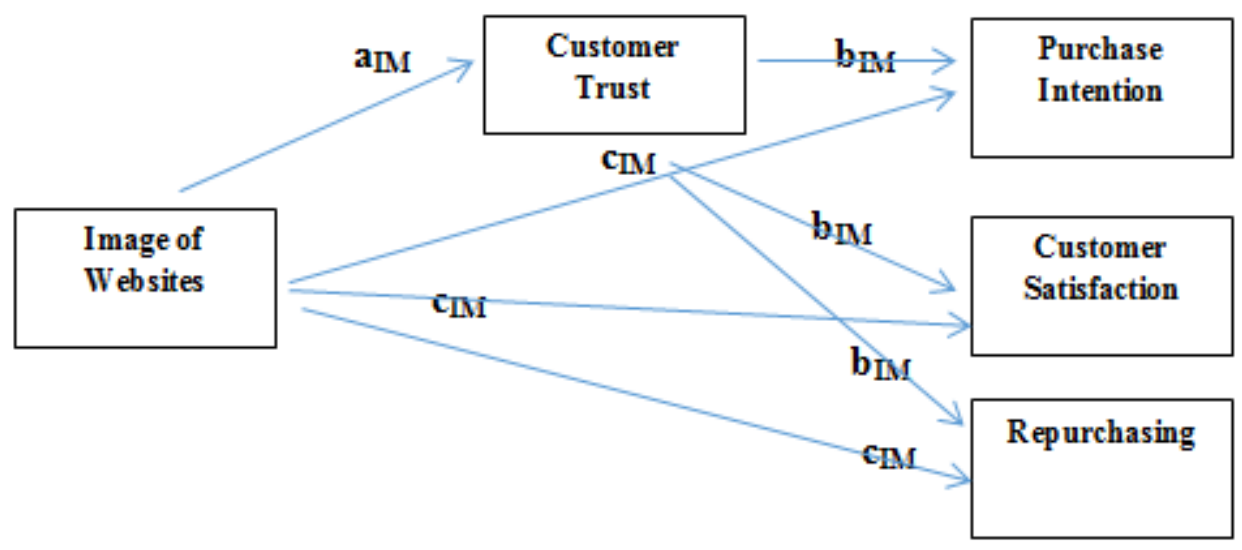

Figure 2: Alternative model 1 for mediation role of customer e-trust

To reveal positive and significant effect of images of websites in the alternative model, regression analysis was performed first, and the results of the analysis were given in Table 4.

Table 4: Linear Regression Analysis for pathways of image of websites on purchase intention, customer satisfaction, repurchase, and e-trust

\begin{tabular}{|c|c|c|c|c|c|c|}
\hline Variables & $\mathbf{F}$ & $\mathbf{R}$ & $\mathbf{R}^{2}$ & $\boldsymbol{\beta}$ & $\mathbf{t}$ & $\mathbf{p}$ \\
\hline IM»PI ( $\left.\mathrm{c}_{\mathrm{IM}}\right)$ & 48.11 & .386 & .363 & .238 & 4.46 & $.000^{* * *}$ \\
\hline $\mathrm{IM} \gg \mathrm{TR}\left(\mathrm{a}_{\mathrm{IM}}\right)$ & 34.23 & .471 & .436 & .244 & 4.19 & $.000 * *$ \\
\hline $\mathrm{TR} \gg \mathrm{PI}\left(\mathrm{b}_{\mathrm{IM}}\right)$ & 133.13 & .542 & .294 & .543 & 11.537 & $.000 * *$ \\
\hline $\mathrm{IM} \gg \mathrm{ST}\left(\mathrm{c}_{\mathrm{IM}}\right)$ & 49.55 & .385 & .378 & .298 & 4.69 & $.003 *$ \\
\hline $\mathrm{TR} \gg \mathrm{ST}\left(\mathrm{b}_{\mathrm{IM}}\right)$ & 114.75 & .417 & .265 & .514 & 10.712 & $.000 * *$ \\
\hline $\mathrm{IM} » \mathrm{RP}\left(\mathrm{c}_{\mathrm{IM}}\right)$ & 80.56 & .636 & .435 & .293 & 5.32 & $.000 * *$ \\
\hline $\mathrm{TR} » \mathrm{RP}\left(\mathrm{b}_{\mathrm{IM}}\right)$ & 103.19 & .543 & .295 & .543 & 11.54 & $.000 * *$ \\
\hline
\end{tabular}




\section{THE RELATIONSHIP BETWEEN DETERMINANTS OF SHOPPING SITES AND CUSTOMER TRUST, PURCHASE INTENTION, SATISFACTION, AND REPURCHASE}

When Table 4 is reviewed, image of websites had a positive and significant effect on purchase intention $(\mathrm{F}=48.11 ; \beta=-.238 ; \mathrm{p}=0.000)$. Path $\mathrm{cIM}$ for purchase intention was provided by this result and $\mathrm{H} 8 \mathrm{a}$ was accepted. It shows the positive and significant effect of image of websites on e-trust $(\mathrm{F}=34.23 ; \beta=-.244 ; \mathrm{p}=0.000)$. Path aIM of purchase intention was provided by this result and $\mathrm{H} 1$ was accepted. Other path bIM was approved by the positive and significant effect of e-trust $(\mathrm{F}=133.13 ; \beta=-.543 ; \mathrm{p}=0.000)$ on purchase intention and $\mathrm{H} 5$ was accepted. Image of websites has a positive and significant effect on customer satisfaction $(F=49.55 ; \beta=-.298 ; p=0.003)$. Path cIM for customer satisfaction was provided by this result and $\mathrm{H} 9 \mathrm{a}$ was accepted. The path aIM was approved by the positive and significant effect of e-trust $(F=114.75 ; \beta=.514 ; p=0.000)$ on customer satisfaction and H6 was accepted. Image of websites had a positive and significant effect on repurchase $(\mathrm{F}=80.56 ; \beta=-.293 ; \mathrm{p}=0.000)$. Path cIM for repurchase was provided by this result and $\mathrm{H} 10 \mathrm{a}$ was accepted. The path aIM was approved by the positive and significant effect of e-trust ( $\mathrm{F}$ $=103.19 ; \beta=.543 ; p=0.000$ ) on repurchase and $\mathrm{H} 7$ was accepted.

Table 5: Multiple Regression Analysis for pathways of image of websites on purchase intention, customer satisfaction, repurchase, and e-trust

\begin{tabular}{|c|c|c|c|c|c|c|}
\hline Variables & $\mathbf{F}$ & $\mathbf{R}$ & $\mathbf{R}^{2}$ & $\boldsymbol{\beta}$ & $\mathbf{t}$ & $\mathbf{p}$ \\
\hline IM» TR»PI & 43.12 & .672 & .451 & .204 & 5.37 & $.000 * *$ \\
\hline $\mathrm{IM} » \mathrm{TR} \gg \mathrm{ST}$ & 41.32 & .637 & .397 & .265 & 2.35 & $.000 * *$ \\
\hline $\mathrm{IM} » \mathrm{TR} \gg \mathrm{RP}$ & 67.111 & .718 & .516 & .243 & 2.66 & $.000 * *$ \\
\hline
\end{tabular}

Reviewing Table 5, when e-trust as an independent variable was added the model for path $\mathrm{c}^{1}$ of purchase intention, according to multiple regression analysis results, in the relationship between purchase intention and image of websites, there was reduction in $\beta$ value significantly $(\beta=.204 ; p=0.000)$ on this effect. In the relationship between customer satisfaction, image of websites, and e-trust for path $\mathrm{c}^{1}$ of customer satisfaction, there was reduction in $\beta$ value significantly $(\beta=.265 ; p=0.000)$ on this effect. For path $c^{1}$ of repurchase, another reduction in the value $\beta(\beta=.243 ; p=0.000)$ is seen as significant in the table to test whether these reductions depended on mediation effect or not, sobel test was conducted.

Table 6: The effects of mediator variable

\begin{tabular}{lcccc}
\hline E-trust( mediator) & $\begin{array}{c}\text { Total } \\
\text { Effect }\end{array}$ & $\begin{array}{c}\text { Direct } \\
\text { Effect }\end{array}$ & $\begin{array}{c}\text { Indirect } \\
\text { Effect }\end{array}$ & $\begin{array}{c}\text { Bootstrap Confidence } \\
\text { Intervals } \\
\text { BoLLCI-BoULCI }\end{array}$ \\
\hline IM»PI & .651 & .286 & .365 & $0.3461-0.5212$ \\
$\mathrm{IM} \gg \mathrm{ST}$ & .484 & .252 & .232 & $0.1537-0.2373$ \\
$\mathrm{IM} \gg \mathrm{RP}$ & .696 & .465 & .231 & $0.2491-0.2765$ \\
& & & &
\end{tabular}


Serhat ATA, Abdulvahap BAYDAŞ \& Mehmet Emin YAŞAR, 2021 Cilt: 22, Sayl: 2, ss.324-349.

For e-trust as a mediator, when checking the difference between total effect and direct effect, the size of indirect effect was found as .79 in the effect of image of websites on purchase intention. Bootstrap confidence intervals show the significance of this difference. The upper level and lower level of this interval must be above or below zero (Preacher \&Hayes, 2008). It can be said that e-trust has a mediating role in the effect of image of websites on purchase intention. So $\mathrm{H}_{11 \mathrm{j}}$ was accepted. In the result it is also seen that interval is above zero so e-trust has a mediating role in the effect of image of websites on customer satisfaction. Therefore, $\mathrm{H}_{11 \mathrm{k}}$ was accepted. The difference between total effect and direct effect, the size of indirect effect was found as .34 and interval is above zero in the effect of image of websites on repurchase. So it can be said that e-trust has a mediating role in this relationship. So $\mathrm{H}_{111}$ was accepted.

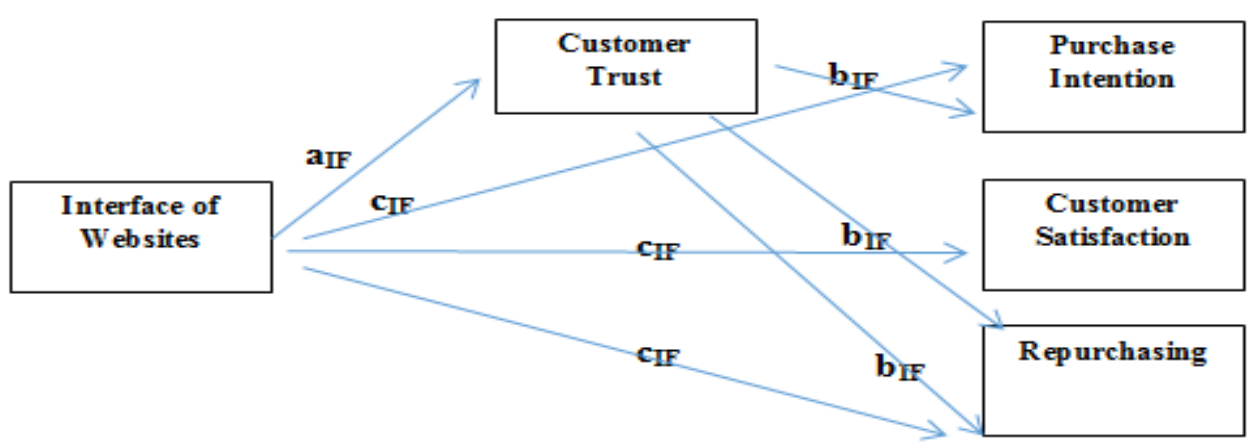

Figure 2: Alternative model 2 for mediation role of customer e-trust

In figure 2 pathways were drawn to show the effect of interface of websites on purchase intention, customer satisfaction, repurchase, and e-trust. Table 7 shows details in this relationship.

Table 7: Linear Regression Analysis for pathways of image of websites on purchase intention, customer satisfaction, repurchase, and e-trust

\begin{tabular}{|c|c|c|c|c|c|c|}
\hline Variables & $\mathbf{F}$ & $\mathbf{R}$ & $\overline{\mathbf{R}^{2}}$ & $\bar{\beta}$ & $\mathbf{t}$ & $\mathbf{p}$ \\
\hline IF»PI ( $\left(\mathrm{c}_{\mathrm{IF}}\right)$ & 59.158 & .442 & .386 & .325 & 5.509 & $.000^{* * *}$ \\
\hline $\mathrm{IF} \gg \mathrm{TR}\left(\mathrm{a}_{\mathrm{IF}}\right)$ & 63.497 & .446 & .239 & .206 & 4.679 & $.000 * *$ \\
\hline $\mathrm{TR} \gg \mathrm{PI}\left(\mathrm{b}_{\mathrm{IF}}\right)$ & 133.13 & .542 & .294 & .543 & 11.537 & $.000 * *$ \\
\hline $\mathrm{IF} \gg \mathrm{ST}\left(\mathrm{c}_{\mathrm{IF}}\right)$ & 11.231 & .255 & .238 & .155 & 2.534 & $.012 *$ \\
\hline $\mathrm{TR} \gg \mathrm{ST}\left(\mathrm{b}_{\mathrm{IF}}\right)$ & 114.75 & .417 & .265 & .514 & 10.712 & $.000 * *$ \\
\hline $\mathrm{IF} » \mathrm{RP}\left(\mathrm{c}_{\mathrm{IF}}\right)$ & 34.165 & 321 & 092 & .338 & 6.158 & $.000 * *$ \\
\hline$T R » R P\left(b_{I F}\right)$ & 103.19 & .543 & .295 & .543 & 11.54 & $.000 * *$ \\
\hline
\end{tabular}




\section{THE RELATIONSHIP BETWEEN DETERMINANTS OF SHOPPING SITES AND CUSTOMER TRUST, PURCHASE INTENTION, SATISFACTION, AND REPURCHASE}

Interface of websites had positive and significant effect on purchase intention $(\mathrm{F}=59.15$; $\beta=.325 ; p=0.000)$, customer e-trust $(F=63.49 ; \beta=-.206 ; p=0.000)$, customer satisfaction $(F=11.23$; $\beta=.155 ; p=0.012)$, and repurchase $(F=34.16 ; \beta=.338 ; p=0.000)$. So, all pathways $c_{I F}$ of interface of websites were extracted and $\mathrm{H}_{8 b}, \mathrm{H}_{9 b}, \mathrm{H}_{10 b}$, and $\mathrm{H}_{2}$ were accepted. The effects of e-trust on purchase intention, customer satisfaction, and repurchase had already been provided in Table 4.

Table 8: Multiple Regression Analysis for pathways of interface of websites on purchase intention, customer satisfaction, repurchase, and e-trust

\begin{tabular}{ccccccc}
\hline Variables & $\mathbf{F}$ & $\mathbf{R}$ & $\mathbf{R}^{2}$ & $\boldsymbol{\beta}$ & $\mathbf{t}$ & $\mathbf{p}$ \\
& & & & & & \\
\hline IF» TR»PI & 49.17 & .473 & .165 & .275 & 6.158 & $\mathbf{. 0 0 0}{ }^{* *}$ \\
IF» TR»ST & 4.473 & .185 & .102 & .089 & 1.740 & .083 \\
IF» TR»RP & 35.84 & .357 & .162 & .294 & 5.438 & $\mathbf{. 0 0 0 * *}$ \\
\hline ** Significant at \%, 1 error level * significant at \% ,5 error level. IF:Interface of websites; PI: Purchase \\
Intention; TR: E-Trust; ST:Customer Satisfaction; RP: Repurchase \\
\hline
\end{tabular}

Table 8 shows that when e-trust as an independent variable was added the model for path $\mathrm{c}^{1}$ of purchase intention, according to multiple regression analysis results, in the relationship between purchase intention and interface of websites, there was reduction in $\beta$ value significantly $(\beta=.275 ; p=0.000)$ on this effect. In the relationship between customer satisfaction, interface of websites, and e-trust for path $c^{1}$ of customer satisfaction, there was reduction in $\beta$ value significantly $(\beta=.089 ; p=0.083)$ on this effect. Although $\beta$ value reduced in the model, it was insignificant. For path $c^{1}$ of repurchase, another reduction in the value $\beta(\beta=.243 ; p=0.000)$ was seen as significant in the Table. To test whether these reductions depended on mediation effect or not, sobel test was conducted.

Table 9: The effects of mediator variable

\begin{tabular}{lcccc}
\hline E-trust ( mediator) & $\begin{array}{c}\text { Total } \\
\text { Effect }\end{array}$ & $\begin{array}{c}\text { Direct } \\
\text { Effect }\end{array}$ & $\begin{array}{c}\text { Indirect } \\
\text { Effect }\end{array}$ & $\begin{array}{c}\text { Bootstrap Confidence } \\
\text { Intervals } \\
\text { BoLLCI-BoULCI }\end{array}$ \\
\hline IF $\gg \mathrm{PI}$ & .287 & .155 & .137 & $0.2321-0.2024$ \\
$\mathrm{IF} \gg \mathrm{ST}$ & .0272 & .0185 & .0087 & $-0.0586-0.1132$ \\
$\mathrm{IF} \gg \mathrm{RP}$ & .276 & .132 & .144 & $0.2123-0.1972$ \\
\hline
\end{tabular}

The fact that being above zero bootstrap confidence intervals showed that e-trust had a mediator role in the effect of interface of websites on purchase intention and repurchase. (Subsequently differences between total and direct effect are .18, .12). So $\mathrm{H}_{11 \mathrm{~g}}$ and $\mathrm{H}_{11 \mathrm{i}}$ were accepted and no mediation role of e-trust in the effect of interface of websites on customer satisfaction was found because lower level of interval was below zero despite upper was above zero. Therefore, $\mathrm{H}_{11 \mathrm{~h}}$ was rejected. 


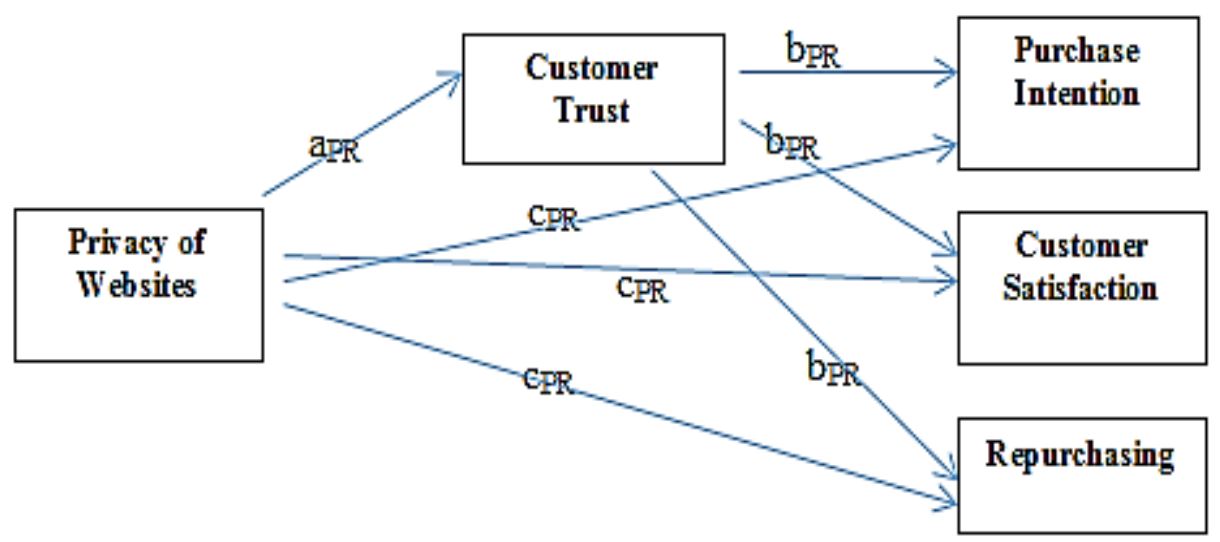

Figure 3: Alternative model 3 for mediation role of customer e-trust

In figure 3 pathways were drawn to show the effect of privacy of websites on purchase intention, customer satisfaction, repurchase, and e-trust. Table 10 shows the details in this relationship.

Table 10: Linear Regression Analysis for pathways of privacy of websites on purchase intention, customer satisfaction, repurchase, and e-trust

\begin{tabular}{|c|c|c|c|c|c|c|}
\hline Variables & $\mathbf{F}$ & $\mathbf{R}$ & $\mathbf{R}^{2}$ & $\beta$ & $\mathbf{t}$ & $\mathbf{p}$ \\
\hline$\overline{\mathrm{PR}} \gg \mathrm{PI}\left(\mathrm{c}_{\mathrm{PR}}\right)$ & 11.69 & .434 & .226 & .144 & 2.350 & $.010^{*}$ \\
\hline $\mathrm{PR} » \mathrm{TR}(\mathrm{aPR})$ & 14.54 & .371 & .188 & .171 & 3.254 & $.007 *$ \\
\hline $\mathrm{TR} \gg \mathrm{PI}\left(\mathrm{b}_{\mathrm{PR}}\right)$ & 133.13 & .542 & .294 & .543 & 11.53 & $.000 * *$ \\
\hline $\mathrm{PR} \gg \mathrm{ST}\left(\mathrm{c}_{\mathrm{PR}}\right)$ & 24.67 & .402 & .211 & .167 & 2.293 & $.004 *$ \\
\hline $\mathrm{TR} » \mathrm{ST}\left(\mathrm{b}_{\mathrm{PR}}\right)$ & 114.75 & .417 & .265 & .514 & 10.712 & $.000 * *$ \\
\hline$P R » R P\left(c_{P R}\right)$ & 9.91 & .352 & .170 & .152 & 2.606 & $.015^{*}$ \\
\hline $\mathrm{TR} \gg \mathrm{RP}\left(\mathrm{b}_{\mathrm{PR}}\right)$ & 103.19 & .543 & .295 & .543 & 11.54 & $.000 * *$ \\
\hline
\end{tabular}

Table 10 shows that privacy of websites had positive and significant effect on purchase intention $(F=11.69 ; \beta=.144 ; p=0.000)$, customer e-trust $(F=14.54 ; \beta=.171 ; p=0.007)$, customer satisfaction $(F=24.67 ; \beta=.167 ; p=0.004)$, and repurchase $(F=9.91 ; \beta=352 ; p=0.015)$. So, all pathways cPR of privacy of websites were extracted and $\mathrm{H}_{8 \mathrm{~d}}, \mathrm{H}_{9 \mathrm{~d}}, \mathrm{H}_{10 \mathrm{~d}}$, and $\mathrm{H}_{4}$ were accepted. The effects of e-trust on purchase intention, customer satisfaction, and repurchase had already been provided in Table 4. 
THE RELATIONSHIP BETWEEN DETERMINANTS OF SHOPPING SITES AND CUSTOMER TRUST, PURCHASE INTENTION, SATISFACTION, AND REPURCHASE

Table 11: Multiple Regression Analysis for pathways of privacy of websites on purchase intention, customer satisfaction, repurchase, and e-trust

\begin{tabular}{ccccccc}
\hline Variables & $\mathbf{F}$ & $\mathbf{R}$ & $\mathbf{R}^{\mathbf{2}}$ & $\mathbf{\beta}$ & $\mathbf{t}$ & $\mathbf{p}$ \\
& & & & & & \\
\hline PR» TR»PI & 9.23 & .344 & .167 & .143 & 2.591 & $\mathbf{. 0 1 5}$ \\
PR» TR»ST & 6.98 & .298 & .138 & .127 & 2.212 & $.028 *$ \\
PR» TR»RP & .78 & .97 & .08 & .020 & .380 & .704 \\
\hline ** Significant at \%, 1 error level * significant at \% ,5 error level. PR:Privacy of websites; PI: Purchase \\
Intention; TR: E-Trust; ST:Customer Satisfaction; RP: Repurchase \\
\hline
\end{tabular}

In table 11 e-trust as an independent variable was added the model for path $\mathrm{c}^{1}$ of purchase intention, according to multiple regression analysis results, in the relationship between purchase intention and privacy of websites, there was little reduction in $\beta$ value significantly ( $\beta=.143$; $\mathrm{p}=0.015$ ) on this effect. In the relationship between customer satisfaction, privacy of websites, and e-trust for path $\mathrm{c}^{1}$ of customer satisfaction, there was reduction in $\beta$ value significantly $(\beta=.127$; $\mathrm{p}=0.028)$ on this effect. For path $\mathrm{c}^{1}$ of repurchase, another reduction in the value $\beta$ ( $\beta=.020$; $\mathrm{p}=0.704$ ) was seen as insignificant in the Table. Although $\beta$ value reduced in the model, it was insignificant. To test whether these reductions depend on mediation effect or not, sobel test was conducted.

Table 12: The effects of mediator variable

\begin{tabular}{lcccc}
\hline E-trust (mediator) & $\begin{array}{c}\text { Total } \\
\text { Effect }\end{array}$ & $\begin{array}{c}\text { Direct } \\
\text { Effect }\end{array}$ & $\begin{array}{c}\text { Indirect } \\
\text { Effect }\end{array}$ & $\begin{array}{c}\text { Bootstrap Confidence } \\
\text { Intervals } \\
\text { BoLLCI-BoULCI }\end{array}$ \\
\hline $\mathrm{PR} \gg \mathrm{PI}$ & .295 & .188 & .107 & $0.1435-0.2302$ \\
$\mathrm{PR} \gg \mathrm{ST}$ & .276 & .132 & .144 & $0.2263-0.1097$ \\
$\mathrm{PR} » \mathrm{RP}$ & .062 & .058 & .004 & $0.086--0.1224$ \\
\hline
\end{tabular}

Being above zero bootstrap confidence intervals show that e-trust has a mediator role in the effect of privacy of websites on purchase intention and customer satisfaction. (Subsequently differences between total and direct effect are .81, .12). So, $\mathrm{H}_{11 \mathrm{~d}}$ and $\mathrm{H}_{11 \mathrm{e}}$ were accepted. No mediation role of e-trust in the effect of privacy of websites on repurchase was found because lower level of interval is below zero despite upper is above zero and $\mathrm{H}_{11 \mathrm{f}}$ was rejected. 
Serhat ATA, Abdulvahap BAYDAŞ \& Mehmet Emin YAŞAR, 2021 Cilt: 22, Sayı: 2, ss.324-349.

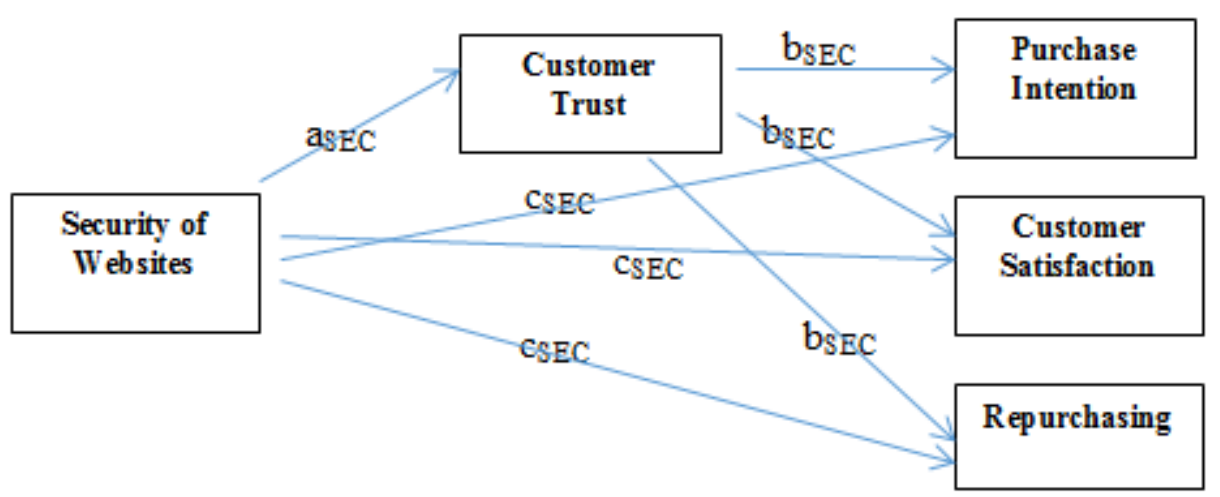

Figure 4: Alternative model 4 for mediation role of customer e-trust

In figure 4 pathways were drawn to show the effect of security of websites on purchase intention, customer satisfaction, repurchase, and e-trust. Table 13 shows details in this relationship.

Table 13: Linear Regression Analysis for pathways of security of websites on purchase intention, customer satisfaction, repurchase, and e-trust

\begin{tabular}{|c|c|c|c|c|c|c|}
\hline Variables & $\mathbf{F}$ & $\mathbf{R}$ & $\overline{\mathbf{R}^{2}}$ & $\beta$ & $\mathbf{t}$ & $\mathbf{p}$ \\
\hline SEC»PI ( $\left.\mathrm{c}_{\mathrm{PR}}\right)$ & 28.11 & .324 & .176 & .158 & 2.772 & $.006^{*}$ \\
\hline $\mathrm{SEC»TR}\left(\mathrm{a}_{\mathrm{PR}}\right)$ & 58.60 & .547 & .265 & .205 & 3.774 & $.000^{* *}$ \\
\hline $\mathrm{TR} \gg \mathrm{PI}\left(\mathrm{b}_{\mathrm{PR}}\right)$ & 133.13 & .542 & .294 & .543 & 11.53 & $.000 * *$ \\
\hline 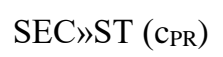 & 11.47 & .302 & .155 & .148 & 2.505 & $.013^{*}$ \\
\hline $\mathrm{TR} \gg \mathrm{ST}\left(\mathrm{b}_{\mathrm{PR}}\right)$ & 114.75 & .417 & .265 & .514 & 10.712 & $.000 * *$ \\
\hline $\mathrm{SEC} \gg \mathrm{RP}\left(\mathrm{c}_{\mathrm{PR}}\right)$ & .67 .43 & .495 & .286 & .258 & 3.929 & $.000 * *$ \\
\hline$T R » R P\left(b_{P R}\right)$ & 103.19 & .543 & .295 & .543 & 11.54 & $.000 * *$ \\
\hline
\end{tabular}

** Significant at \%, 1 error level * significant at \% ,5 error level. SEC:Security of websites;

PI: Purchase Intention; TR: E-Trust; ST:Customer Satisfaction; RP: Repurchase

Security of websites had positive and significant effect on purchase intention $(\mathrm{F}=28.11$; $\beta=.158 ; p=0.006)$, customer e-trust $(F=58.60 ; \beta=.205 ; p=0.000)$, customer satisfaction $(F=11.47$; $\beta=.148 ; p=0.013)$, and repurchase $(F=67.43 ; \beta=258 ; p=0.000)$. So, all pathways cSEC of security of websites were extracted and $\mathrm{H}_{8 c}, \mathrm{H}_{9 c}, \mathrm{H}_{10 c}$, and $\mathrm{H}_{3}$ were accepted. The effects of e-trust on purchase intention, customer satisfaction, and repurchase had already been provided in Table 4. 


\section{THE RELATIONSHIP BETWEEN DETERMINANTS OF SHOPPING SITES AND CUSTOMER TRUST, PURCHASE INTENTION, SATISFACTION, AND REPURCHASE}

Table 14: Multiple Regression Analysis for pathways of security of websites on purchase intention, customer satisfaction, repurchase, and e-trust

\begin{tabular}{ccccccc}
\hline Variables & $\mathbf{F}$ & $\mathbf{R}$ & $\mathbf{R}^{2}$ & $\boldsymbol{\beta}$ & $\mathbf{~ t}$ & $\mathbf{p}$ \\
& & & & & & \\
\hline SEC» TR»PI & 2.23 & .044 & .021 & .033 & 1.030 & .555 \\
SEC» TR»ST & 4.65 & .321 & .155 & .108 & 1.817 & .070 \\
SEC» TR»RP & 55.03 & .403 & .226 & .179 & 3.345 & $.001 * *$ \\
\hline ** Significant at \%, 1 error level * significant at \% ,5 error level. SEC:Security of websites; PI: Purchase \\
Intention; TR: E-Trust; ST:Customer Satisfaction; RP: Repurchase \\
\hline
\end{tabular}

Table 14 shows that when e-trust as an independent variable was added the model for path $\mathrm{c}^{1}$ of purchase intention, according to multiple regression analysis results, in the relationship between purchase intention and interface of websites, there was reduction in $\beta$ value but it was insignificant $(\beta=.033 ; p=0.555)$ In the relationship between customer satisfaction, security of websites, and e-trust for path $\mathrm{c}^{1}$ of customer satisfaction, there was reduction in $\beta$ value but it was insignificant $(\beta=.108 ; p=0.070)$ on this effect. For path $c^{1}$ of repurchase, another reduction in the value $\beta(\beta=.179 ; p=0.001)$ was seen as significant in the table. To test whether these reductions depend on mediation effect or not, sobel test was conducted.

Table 15: The effects of mediator variable

\begin{tabular}{lcccc}
\hline E-trust( mediator) & $\begin{array}{c}\text { Total } \\
\text { Effect }\end{array}$ & $\begin{array}{c}\text { Direct } \\
\text { Effect }\end{array}$ & $\begin{array}{c}\text { Indirect } \\
\text { Effect }\end{array}$ & $\begin{array}{c}\text { Bootstrap Confidence } \\
\text { Intervals } \\
\text { BoLLCI-BoULCI }\end{array}$ \\
\hline SEC»PI & .087 & .065 & .0022 & $-0.0035-0.0002$ \\
SEC»ST & .176 & .089 & .087 & $-0.2263-0.1097$ \\
SEC»RP & .326 & .172 & .154 & $-0.186--0.1224$ \\
\hline
\end{tabular}

Confidence intervals showed the size of mediator effect of e-trust in the relationship. It is seen that e-trust only had a mediator role in the effect of security of websites on repurchase due to having lower zero intervals. So $\mathrm{H}_{11 \mathrm{c}}$ was accepted. The size of this effect was .18 when looking the differences between total effect and direct effect. By all these results, $\mathrm{H}_{11 \mathrm{a}}$ and $\mathrm{H}_{11 \mathrm{~b}}$ were rejected.

The relationships between the variables of the current study model and the analysis results regarding the direction of these relationships and the effects of the variables on each other were presented in detail in the section above. In the studies conducted within the scope of the literature, determinations, and evaluations were seen in parallel with the analysis results of this study. In the results of the current study hypotheses, it was found that website identifiers had a significant effect on purchase intention, customer satisfaction, and repurchase and e trust- had a partly mediator role. 
Serhat ATA, Abdulvahap BAYDAŞ \& Mehmet Emin YAŞAR, 2021 Cilt: 22, Sayl: 2, ss.324-349.

\section{CONCLUSION}

Findings attained from the result of the research, are crucial in terms of examining the effects of image, interface, security, and privacy on the purchase intention, customer satisfaction, and repurchase of customer. However, distinctive part of this study is to reveal the mediating role of the customer e-trust on this relationship. In the online purchasing process, the consumer may experience anxiety about the actual purchase. The environment of e-trust provided to the consumer together with the website and its components plays an important role in this concern. Consumers can lose their trust in the e-business if their deliveries arrive late or if the incoming delivery is damaged/defective, and thus avoid online shopping. E-commerce businesses can enable consumers to make repurchases if they deliver the product to the consumer as soon as possible and under the most favorable conditions by protecting personal data with web design and focusing on logistics operations and deliveries. The anxiety of "the decision is right or not" in the consumer during or after the purchase should be reduced by using the right tools. These tools consist of many options such as good website design and appearance, secure payment option, and protection of personal data. All these tools are elements that will create a sense of e-trust in the consumer and will shape the purchasing behavior.

Determinants of the website are considered factors that provide e-trust for customers and play a role between purchase intentions, satisfaction, and repurchase process of customers. When the literature is examined, it is seen that according to the findings of Aydin and Derer (2015), the bad experiences customers have with the website or the distrust towards companies engaged in electronic commerce affect their purchasing behavior and pattern. Besides, Azhar et al. (2021) in their research on customers using an application for online shopping found that e-service quality and e-trust have an influence on e-satisfaction.

The current growth of online shopping and the subsequent diffusion of the Internet in both developed and developing countries have brought new challenges and opportunities to the ecommerce business. Therefore, it becomes vital to understand the behavior of online consumers and identify factors that influence online buying behavior. When thinking in line with this, customer purchase intention satisfaction and repurchasing intention are the assurance of the continuity of the company's existence and earnings. So, e-commerce business should consider the ways of gaining e-trust since the rapid growth of online shopping types provides many conveniences in aspects of life for customers. Overall, the study provides some of the key insights to e-commerce businesses regarding purchase intention satisfaction and purchasing variables of consumers. This significantly influences the online buying behavior of consumers and would help e-commerce businesses in strategizing both for website designing and development and for market development and segmentation. 
THE RELATIONSHIP BETWEEN DETERMINANTS OF SHOPPING SITES AND CUSTOMER TRUST, PURCHASE INTENTION, SATISFACTION, AND REPURCHASE

\section{RESEARCH LIMITATIONS AND SUGGESTIONS FOR FUTURE STUDIES}

The most important limitation in the findings of this study is that the study only covered the consumers in a certain city. Website user intentions may vary in different cities, cultures, countries, regions, and education levels. In future studies, in addition to these variables, hedonic purchasing, following fashion, planned purchasing behaviors, as well as brand perception, which are effective in customers' preference of online shopping sites, can be added to examine their effect on existing variables. There are not many studies in the literature about e-trust, which is an important subject of electronic commerce. It is considered to contribute to the literature regarding e-trust as a mediator in models. In addition, in future studies, it is possible to conduct research with larger sample size and to compare various shopping sites. 
Serhat ATA, Abdulvahap BAYDAŞ \& Mehmet Emin YAŞAR, 2021 Cilt: 22, Sayl: 2, ss.324-349.

\section{REFERENCES}

Akroush, M. N., \& Al-Debei, M. M. (2015). An Integrated Model of Factors Affecting Antecedents. Decision Support Systems, 44(2), 544-564.

Aydın, S., \& Derer, E. (2015). E-ticarette Güven Unsurunun Müşterilerin Satın Alma Davranışlarına Olan Etkisi: Süleyman Demirel Üniversitesi Öğrencileri Üzerine Bir Araştırma. Süleyman Demirel Üniversitesi Sosyal Bilimler Enstitüsü Dergisi, (21), 127 150.

Bilgi İletişim Teknolojileri ve Enerji Dergisi. (2020, 11 Ocak). 2020 Y1lı Online Alışveriş İstatistikleri Açıklandı. https://www.ictmedia.com.tr/News/Index/10439/2020-yili-onlinealisveris istatistikleri-aciklandi.

Chen, M. Y., \& Teng, C. I. (2013). A Comprehensive Model of The Effects of Online Store İmage on Purchase Intention in An E-Commerce Environment. Electronic Commerce Research, 13(1), 1-23.

Cyr, D., Head, M., Larios, H., \& Pan, B. (2009). Exploring Human Images in Website Design: A Multi-Method Approach. MIS Quarterly, 539-566.

Çelik, Z., \& Dülek, B.(2020). Mutluluk-Davranış Modeli: Tüketicilerin Mental İyi Oluş Hâlinin Online Fiili Satın Alma Davranışına Etkisi. Beykoz Akademi Dergisi, 8(1), 252-264.

Ginosar, A., \& Ariel, Y. (2017). An Analytical Framework for Online Privacy Research:Haque, U. N., \& Mazumder, R. (2020). A Study on The Relationship Between Customer Loyalty and Customer E-Trust in Online Shopping. International Journal of Online Marketing (IJOM), 10(2), 1-16.

Hausman, A. V., \& Siekpe, J. S. (2009). The Effect of Web Interface Features on Consumer Online Purchase Intentions. Journal of Business Research, 62(1), 5-13.

Hayes, A. F. (2018). Partial, Conditional, and Moderated Moderated Mediation: Quantification, Inference, and Interpretation. Communication Monographs, 85(1), 4-40.

Hsiao, M. H. (2009). Shopping Mode Choice: Physical Store Shopping Versus E-Shopping. Transportation Research Part E: Logistics and Transportation Review, 45(1), 86-95.

Husain, T. (2019). Analisis Layanan Google Scholar Sebagai Bahan Referensi Terhadap Kepuasan Mahasiswa. Ultima Infosys: Jurnal Ilmu Sistem Informasi, 10(1), 69-75.

Islam, H., Jebarajakirthy, C., \& Shankar, A. (2021). An Experimental Based Investigation into The Effects of Website Interactivity on Customer Behavior in on-Line Purchase Context. Journal Of Strategic Marketing, 29(2), 117-140.

Ideasoft. (2021). https://www.ideasoft.com.tr/.

Jones, G.R \& George, J. (1998). The Experience and Evolution of Trust: Implications for Cooperation and Teamwork. Academy of Management Review 23(3), 531-546.

Kim, D. J., Ferrin, D. L., \& Rao, H. R. (2008). A Trust-Based Consumer Decision-Making Model in Electronic Commerce: The Role of Trust, Perceived Risk, and Their Antecedents. Decision support systems, 44(2), 544-564.

Kuo, H. M. (2006). Discussion of the Interfering Factors for Internet Shopping. In Conference on Theories and Practices in International Business, Chang Jung Christian University (P. 52). 
THE RELATIONSHIP BETWEEN DETERMINANTS OF SHOPPING SITES AND CUSTOMER TRUST, PURCHASE INTENTION, SATISFACTION, AND REPURCHASE

Lal, M., \& Katole, H. (2021). Website Personality: A Theoretical Study. Psychology and Education Journal, 58(2), 4041-4051.

Lee, Y. J., Yang, S., \& Johnson, Z. (2017). Need for Touch and Two-Way Communication in ECommerce. Journal of Research in Interactive Marketing.

Leonidou, L. C., Leonidou, C. N., \& Kvasova, O. (2013). Cultural Drivers and E-Trust.

Liu, C., Marchewka, J. T., \& Ku, C. (2004). American and Taiwanese Perceptions Concerning Privacy, E-Trust, and Behavioral İntentions in Electronic Commerce. Journal of Global Information Management (JGIM), 12(1), 18-40.

Nguyen, N., \& Leblanc, G. (2001). Corporate Image and Corporate Reputation in Outcomes of Consumer Perceptions of Organizational Unethical Marketing.

Patel, V., Das, K., Chatterjee, R., \& Shukla, Y. (2020). Does the Interface Quality of Mobile Shopping Apps Affect Purchase İntention? An Empirical Study. Australasian Marketing Journal (AMJ), 28(4), 300-309.

Preacher, K. J., \& Hayes, A. F. (2008). Asymptotic and Resampling Strategies for Assessing and Comparing Indirect Effects in Multiple Mediator Models. Behavior Research Methods, 40(3), 879-891.

Qalati, S. A., Vela, E. G., Li, W., Dakhan, S. A., Hong Thuy, T. T., \& Merani, S. H. (2021). Effects of Perceived Service Quality, Website Quality, and Reputation on Purchase Intention: The Mediating and Moderating Roles of E-Trust and Perceived Risk in Online Shopping. Cogent Business \& Management, 8(1), 1869363.

Ratnasari, I., Siregar, S., \& Maulana, A. (2021). How to Build Consumer E-Trust Towards ESatisfaction in E-Commerce Sites in the Covid-19 Pandemic Time?. International Journal of Data and Network Science, 5(2), 127-134.

Rehman, S. U., Bhatti, A., Mohamed, R., \& Ayoup, H. (2019). The Moderating Role of E-Trust and Commitment Between Consumer Purchase Intention and Online Shopping Behavior in the Context of Pakistan. Journal of Global Entrepreneurship Research, 9(1), 1-25.

Rita, P., Oliveira, T., \& Farisa, A. (2019). The Impact of E-Service Quality and Customer Satisfaction on Customer Behavior in Online Shopping. Heliyon, 5(10), E02690.

Rust, R. T., \& Zahorik, A. J. (1993). Customer Satisfaction, Customer Retention, and Market Share. Journal of Retailing, 69(2), 193-215.

Seckler, M., Heinz, S., Forde, S., Tuch, A. N., \& Opwis, K. (2015). E-trust and Dise-Trust on the Web: User Experiences and Website Characteristics. Computers in Human Behavior, 45, 39-50.

Shergill, G. S., \& Chen, Z. (2005). Web-Based Shopping: Consumers'attıtudes Towards Online Shopping in New Zealand. Journal of Electronic Commerce Research, 6(2), 78.

Shodiq, A. F., Hidayatullah, S., \& Ardianto, Y. T. (2018). Influence of Design, Information Quality and Customer Services Website on Customer Satisfaction. International Journal of Scientific \& Engineering Research, 9(12), 746-750. 
Serhat ATA, Abdulvahap BAYDAŞ \& Mehmet Emin YAŞAR, 2021 Cilt: 22, Sayı: 2, ss.324-349.

Sönmezay, M. (2019). E-Ticarette Tüketici Güvenini Etkileyen Faktörler ve Tüketicilerin Online Satın Alma Niyeti Üzerinde Güvenin Etkisi: Tüketiciler Üzerinde Bir Araştırma [Yüksek Lisans Tezi]. Bursa Uludağ Üniversitesi.

Suhaily, L., \& Soelasih, Y. (2017). What Effects Repurchase Intention of Online Shopping. International Business Research, 10(12), 113-122.

Tirtayani, I. G. A., \& Sukaatmadja, I. P. G. (2018). The Effect of Perceived Website Quality, ESatisfaction, and E -Trust Towards Online Repurchase Intention. International Journal of Economics, Commerce and Management, 6(10), 262-287.

TÜİK. (2021). https://www.tuik.gov.tr/. 


\section{THE RELATIONSHIP BETWEEN DETERMINANTS OF SHOPPING SITES AND CUSTOMER TRUST, PURCHASE INTENTION, SATISFACTION, AND REPURCHASE \\ EXTENDED ABSTRACT}

E-commerce is a substantial technology that runs a variety of services and the facility to look through a wide range of products and services to select from, it provides much information concerning certain products and services and it comforts customers to get more information in less time and make better decisions and acquire the best deals.

Even though online shopping must turn into an emergent new trend and an important purchasing channel, customers are still not very satisfied with the current case of the shopping style. The most significant point triggering customers towards dissatisfaction is natural inadequacy for providing physical product experiences such as touching that is a sensory stimulus. No-touch causes a considerable obscurity related to the products and triggers dissatisfaction.

Although there are many studies on e-commerce and shopping site in the world, there are not many studies conducted in Turkey about the relationship between website determinants and online customer e-trust and satisfaction repurchase intention. Nowadays, as the rate of online shopping increases every year both in the world and in Turkey, it is important for businesses to determine which criteria will provide a competitive advantage. From this point of view, it is seen that the element of e-trust is one of the most important criteria when shopping online. When most factors are categorized for determinants of websites in this study, image, interface, security, and privacy of websites for shopping are reviewed and conducted in the analysis.

A good website image may cause an e-commerce business to be perceived as delivering high quality, innovative offers, and excellent operational transactions. In e-commerce, e-trust has been shown to have an important positive influence on the intention to buy a product. A positive website image can increase security, e-trust, and purchase intent, as the usability reflects the structure of a system, the simplicity of using the website, the speed of locating an item, ease of perception on the website, consistent design patterns, and the ability to control users' movements within the system. Moreover, security is also the most important factor in building e-trust. Although many online shopping sites have been secured with coding systems, people remain insecure.

To alleviate customers' anxieties regarding privacy, websites organizations in worldwide have activated subject privacy policies or statements on their websites. These are descriptions of sites applying the online collection, use, and spreading of personal information. Lack of e-trust, which is one of the basic requirements for building online shopping relationships, can play an important deterrent role in online shopping. Satisfaction is thoroughly associated with customer attitudes and intentions, which are parts of customer behavior and directly impact customers' positive behavioral intentions. Also, a brand of a website is a more critical indicator for customers than website quality and this refers to the awareness of a website. Furthermore, the study reveals that e-trust is a mediator in this relationship. Because website quality effects the e-trust, so, the etrust based on this relation effects satisfaction, repurchase intention.

The aim of this study is to disclose the mediating role of customer e-trust in the relationship between determinants of shopping websites and online purchase intention, satisfaction, and repurchase intention of customers. The population of the research consists of consumers preferring online shopping. The study sample consists of 321 consumers who reside in Bingöl, Turkey. Participants were selected by a random method and out of online shopping, criterion were not included in the survey. In the research, the survey technique, one of the quantitative research methods, was chosen as the data collection method. The questionnaire form was applied in Bingöl 
province of Turkey and via e-mail between September and December 2020. The convenience sampling method was used in the choice of the people participating in the study.

Determinants of the website are considered factors that provide e-trust for customers and play a role between purchase intentions, satisfaction, and repurchase process of customers. To reveal the relationship between determinants of the website (independent variables) and purchase intention, customer satisfaction, and repurchase (dependent variables) and to test mediating effects of e-trust on this relationship multiple regression analysis were conducted. However, distinctive part of this study is to reveal the mediating role of customer e-trust on this relationship. In line with this, findings show that image, interface, security, and privacy sub-dimensions of web determinants effect positively and meaningful purchase intention, customer satisfaction, and repurchase of customers. Besides, it was found that e-trust has a partial mediating role in this relationship.

The current growth of online shopping and the subsequent diffusion of the Internet in both developed and developing countries have brought new challenges and opportunities to the ecommerce business. Therefore, it becomes vital to understand the behavior of online consumers and identify factors that influence online buying behavior. When thinking in line with this, customer purchase intention satisfaction and repurchasing intention are the assurance of the continuity of the company's existence and earnings. So, e-commerce business should consider the ways of gaining e-trust since the rapid growth of online shopping types provides many conveniences in aspects of life for customers. Overall, the study provides some of the key insights to e-commerce businesses regarding purchase intention satisfaction and purchasing variables of consumers. This significantly influences the online buying behavior of consumers and would help e-commerce businesses in strategizing both for web site designing and development and for market development and segmentation.

The most important limitation in the findings of this study is that the study only covers the consumers in a certain city. Website user intentions may vary in different cities, cultures, countries, regions, and education levels. In future studies, in addition to these variables, hedonic purchasing, following fashion, planned purchasing behaviors, as well as brand perception, which are effective in customers' preference of online shopping sites, can be added to examine their effect on existing variables. There are not many studies in the literature about e-trust, which is an important subject of electronic commerce. It is considered to contribute to the literature regarding e-trust as a mediator in models. In addition, in future studies, it is possible to conduct research with larger sample size and to compare various shopping sites. 